\title{
The Effect of Using Computer Games on Lower Basic Stage Students' Achievement in English at Al-Salt Schools
}

\author{
Abeer Rashed Al-Elaimat ${ }^{1}$ \\ ${ }^{1}$ Princess Rahma-College, Al-Balqa-Applied University, Alsalt, Jordan \\ Correspondence: Abeer Rashed Al-Elaimat, Assistant Professor, Princess Rahma-College, Al-Balqa-Applied \\ University, Alsalt, Jordan. Tel: 962-776-264-029. E-mail: Mohammedolimat29@yahoo.com
}

Received: December 3, 2012 Accepted: December 19, 2012 Online Published: January 13, 2013

doi:10.5539/ies.v6n2p160 URL: http://dx.doi.org/10.5539/ies.v6n2p160

\begin{abstract}
The purpose of this study is to investigate the effect of using computer games on the lower basic stage student's achievement in learning English at Al-SALT Schools.

The population of this study consisted of all lower basic stage students in AL-SALT schools during the scholastic year 2011-2012. However, the sample of this study consisted of 88 male and female third grade students divided into tow groups, the experimental group whichunderwentateaching.
\end{abstract}

Experiment using computer games, and control group using the traditional method.

The instrument of the study was an achievement test that aimed at measuring students' performance. The independent variables were the teaching method, technique and the computer games. The dependent variable was the student's achievement in English.

The findings of the study revealed significant differences in the mean scores between the control and the experimental groups, students' performance of experimental group was better than that of the control group.

Keywords: computer games, lower basic stage students, achievement

\section{Introduction}

Many people consider games just as a means of entertainment and not as part of the educational software. Despite the controversy over games effectiveness in the teaching and learning process, instructional games are believed to be useful for reinforcing and assessing learning (Williams, 1985). Lewis (1999) says that the use of instructional games in teaching English as a foreign language in classroom is beneficial because students often learn in an unconscious and stress-free atmosphere. Lewis argues that games add variation to a lesson and increase motivation by providing a great incentive to use the target language.

Researchers have explored the potential of computer games in promoting learning and some have found positive effects of computer games on learning. Computer games can provide repeated and effective practice that learners need to build automaticity of their language skills in the target language (Stephenson \& Rumley, 2005). In addition, computer games allow for a great deal of learner control, freedom and flexibility that learners usually enjoy.Games promote interest and motivation in learners as they are fun and engaging (Hansson, 2005).Computer games also often provide instant feedback that lets learners know immediately if they have given the wrong answer, which is necessary in the language acquisition process (Gass, 1997). Learners can play the game again to correct their errors (Richard-Amato, 1988).

Moreover, instructional games are used to achieve social objectives, improve the students' self concept, develop their verbal ability, and help them express their feelings and excitement to the learning task (Cratty; 1969; Williams, 1985). Instructional games are believed to be one of the techniques that increase activity and makes learning a pleasant experience, joy, fun and humor (Rieber 1996).

Gardner (1998) pointed out that instructional games play an essential role in the teaching process. They provide students with a secure environment while participating in the language skills task. Games equip teachers with the needed means to overcome the obstacles encountered during the teaching process. While adapting instructions games, the teacher pays special attention to individual differences among students. Amory and Adams (1999) pointed out that the development of learning tools based on the computer games could provide educators with a 
suspensor mechanism to persuade learners in virtual environments where knowledge is acquired through intrinsic motivation.

Language is acquired through practice. It is very important for the teachers to look for a communicative situation which "brings a foreign language to life in the classroom. Games can link language with action (Lee, 1987).

Using instructional games requires teachers to plan in advance for what they have to do and provide students with the necessary materials. Kim (1995) argues that using educational games makes the learning process an enjoyable activity for students and outlines a set of prerequisite conditions while using the educational games in language classroom activities:

The goals of the games should be pre- planned.

The games should suit students' ages and their mental abilities.

The games should motivate students to think, notice, observe and compare.

The games should be carried out in classroom.

According to Betz (1995), computer games tend to have three characteristics that make them of interest to educators:

1) They are attention grabbing and holding for many people.

2) They can be designed to provide types of interactivity and motivation.

3) They provoke interactivity and motivation among students and facilitate interaction between large numbers of people playing the game.

The teaching computergames are methodological way in thinking and organized way in working handling all the factors included in the teaching process, due to the importance of developing the methods of teaching the English and paying attention to it as part of means of executing the curriculum and achieving its goals by carrying its different content and activities and moving from method of teaching the English from the conventional method to modern concept, the idea of applying the method of modern and diversity teaching method, such as computer games method and strategy. The problem of the study can be formed as follows:

What is the impact of using the strategy of the computergames in the achievement in the English subject?

\section{Statement of the Problem and Questions}

This study is an attempt to find whether using computer games and the individual, pair and group technique could be useful for learning English. After searching the Internet, libraries of the universities and specialized journals, it seems no study to date has studied the individuals, pairs or groups technique for using computer games in language teaching and learning. This study attempts to answer the following questions:

Are there any significant statistical differences $(\mathrm{P} . \leq .05)$ on the lower basic stage students' achievement in English attributed to learning by computer games or the traditional method?

Are there any significant statistical differences $(\mathrm{P} . \leq .05)$ on the students' achievement attributed to the technique of teaching (individuals, pairs and groups)?

Are there any significant statistical differences $(\mathrm{P} . \leq .05)$ on the student's achievement attributed to the interaction between the activity type and the technique of teaching (groups, pairs and individuals)?

This study attempts to improve the quality of English language teaching by focusing on computer games and the appropriate technique (individual, pair and group) of teaching. Therefore, it is important because it may help teachers and curricula designers to choose the best method and technique of teaching English language. In addition, it provides teachers with computerized games which may help them in teaching English. At the same time, this study is an attempt to motivate teachers and curricula designers to integrate games in English curricula. As a result, students' performance in English may improve.

\section{Definition of Terms}

The following terms have the designated meanings wherever they are used in this study:

Traditional method of teaching: It refers to teaching without the aid of computers which is often used in classrooms (using blackboard and chalk).

Activity type: It includes the following activities which are related to the third grade English

Technique: A particular way of teaching students. In this study, it is the way of teaching through groups, pairs and individuals. 
Achievement: It measures what students acquire in the learning process.

Games: In the context of the current study, they are entertainment activities. Games are instructional tools to help students acquire English language.

\section{Review of Related Literature}

Studies about using computer games in teaching a language Atiyat (1992) investigated the effect of computer instructional games upon tenth grade students' mastering of English vocabulary. The sample of the study consisted of 123 tenth grade students. The results of the study indicated that there was a significant difference in the achievement of learning English vocabulary between the experimental and control groups in favor of the experimental group.

Alfaqih (1995): investigated the effectiveness of using computer games as opposed to the traditional method in teaching Jordanian EFL seventh graders. The results showed that there were statistically significant differences due to utilizing computer games. However, there were no significant differences attributed to the interaction between method of instruction and sex.

$\mathrm{Al}$ abbadi (2005): carried out a study to investigate the effect of computer games as an instructional tool on third grade students' acquisition of higher order thinking skills. The result of the study revealed significant differences among students in the experimental group, indicating a significant effect of computers games on acquiring higher order thinking skills.

Shdaifat (2006) investigated the effect of using computerized instructional games on EFL second grade pupils learning of vocabulary. The result revealed that the use of computerized instructional games motivate students towards learning and a relaxed atmosphere in classroom.

Sorenson (2009): argued that the general potential of computer games for teaching and learning is becoming widely recognized. In particular, within the application contexts of primary and lower secondary education, the relevance and value of computer games seemed more accepted, and the possibility and willingness to incorporate computer games as a possible resource at the level of other educational resources seemed more frequent. The study adopted an explorative research design approach and investigated and analyzed the learning and social effects that appeared in the classroom as a result of using computer games approach. The findings suggested that the incorporation of learning games at the high school level had much uncovered potential to offer processes of teaching and learning.

Peterson (2010): examined the psycholinguistic and sociocultural constructs proposed as a basis for the use of games and simulation in computer -assisted learning. The author reviewed key finding from influential studies. The authors' analysis revealed that, although these studies are subject to limitation, simulations and games present valuable opportunities for language effective language learning. The contemporary literature on theories hypothesizes the simulation and games are beneficial methods for helping learners acquire another language.

All the studies reviewed above showed that teaching using computer games plays a major role in language learning. The present study is similar to the reviewed studies in the general aim which is the effect of computer games on the learning English. To my best knowledge, it seems no study has addressed the issue of the best technique of teaching computer games (groups, pairs and individuals), a gap to be bridged in this study.

\section{Methodology and Procedures}

The population of this study consisted of all lower basic stage male and female students at Al- salt Directorate of Education.

The sample of the study consisted of 88 third grade male and female students in the second semester 2011-2012 at Al-SALT School.

This study has the following variables:

The independent variables are:

The treatment technique (teaching activities in groups, pairs and individuals).

The method of teaching (traditional method and computer games).

The dependent variable is the students' achievement in English (i.e. students' scores in the post test).

\section{The Instruments of the Study}

To achieve the purpose of the study, the researcher used the following instruments: an achievement test and computer games. 


\section{The Achievement test}

The researcher developed an achievement test (see appendix A) to measure students' achievement before and after participating in the study. The achievement test consisted of three questions. The first question was gap filling. The second was crossword. The third was a matching exercise. Each question had three alternatives and the total score for achievement test was 45 .

Using Action Pack 3 textbook and after analyzing the syllabus content, the researcher modified the text to cover all the domains on this study. Accordingly, the achievement test was developed to the content and objectives of lessons based on five units of the third grade textbook, Action Pack 3.

\section{The Computer games}

The second instrument was computer games. A computer program was designed by the researcher. The content of these games was taken from Action Pack 3. The data were changed into computer games by using Flash software. The researcher used this kind of software because it has the ability to process items individually in a graphical way (drag and drop, for example) and also to take various processing by discussion and addition. It gives the learners a direct feedback which gives them considerable felicity. On the other hand, Flash software allows the learner to create dragged objects and place a dynamic text on the object. Students can also change the content of the exercise easily. At the same time, the screen consists of a table of content button (next and back) so that a student can repeat the game easily or the student can quit an exercise and practice another one.

The computer games program consists of the following: the home page presents an opening screen including the title of the program, the class and the researcher's name. The second screen includes a table of content buttons (next and back) and the teacher's overview, which is a teacher's guide that may be used before each game. If the student wants to quit an exercise and practice another one, helshe can click on the main button to go back to the table of content. The other screens consist of ten lessons from five units. These games took different shapes: crosswords, matching, filling gaps, guessing words and listening to text. The instructional games were designed to cover the following topics:

Animals

Months

Clothes

Colors

Food

Verbs

Adjectives

Family

\section{Validity of the Test}

The test was given to three TEFL professors, two English language supervisors and six language teachers who teach Action Pack 3 to evaluate it and suggest changes. The test was modified according to their remarks. For example, more instructions were given to the students to help them carry out the tasks successfully.

\section{Reliability of the test}

The researcher used the test retest technique to determine the reliability of the test. The test was administrated twice to twenty students with a two week period between the test and the retest. The twenty students were not included in the sample. The reliability Coefficient of the test was calculated. It was 0.84 which is statistically acceptable for the purpose of the study.

\section{Reliability and Validity of the Computer Games Program}

The computer program was given to a group of language specialists and a group of instructional technology specialists at Al al-Bayt University and Yarmok University. They were asked to give their opinions about the fitness and appropriateness of the program items for the third grade students. They were also asked to give their opinions about the consistency of the items to Action Pack 3.

Based on the opinions of the specialists, additional instructions were added to some games and additional page was added to introduce the objectives of the program. 
To ensure more validity, the researcher administrated the computer program on a sample of the population of the study. The students were satisfied, and there were no significant remarks reported.

\section{Statistical analysis}

The analysis of covariance (ANCOVA) was used to account for the differences that may arise as a result of the treatment of the study. The ANCOVA was also used to compare the adjusted post means of the students' scores with their mean scores in the pre test, taking into account the difference between the students' achievement on the pre test.

\section{Findings}

The findings of this study revealed that the scores of the two groups were almost equivalent in the pre test before applying the experiment. There was no statistically significant difference between the mean scores of the two groups as shown in Table 1.

Table 1. Means and Standard Deviation of the Control and the Experimental Groups on the Pre Test

\begin{tabular}{llllllll}
\hline & & & & Std. & & Sig. \\
(2-tailed)
\end{tabular}

*Std=standard

Table 1 shows that the mean scores for both the experimental and the control groups were equivalent.

As for the post test, the means and the standard deviations of the two groups were calculated. The mean scores of the experimental and the control groups were 34.35 and 25.63 respectively (see Table 2. It is obvious that the mean scores of the experimental group in the post test were higher than those of the control group. The differences could be attributed to the treatment. The mean scores of the groups and the standard deviation were calculated. The differences in the mean scores of the two groups show that the treatment has influenced the students' performance, the significant differences between the two groups nmwere .003 . Table 2 below shows the results.

Table 2. Means and Standard Deviation of the Control and the Experimental Groups on the Post Test

\begin{tabular}{|c|c|c|c|c|c|c|c|}
\hline & GROUP & $\mathrm{N}$ & Mean & $\begin{array}{l}\text { Std. } \\
\text { Deviation }\end{array}$ & $\mathrm{T}$ & $\mathrm{df}$ & $\begin{array}{l}\text { Sig. } \\
\text { (2-tailed) }\end{array}$ \\
\hline \multirow[t]{2}{*}{ Filling gaps } & $\begin{array}{l}\text { EXPERIMENTA } \\
\mathrm{L}\end{array}$ & 48 & 10.56 & 3.038 & \multirow[t]{2}{*}{4.679} & \multirow[t]{2}{*}{86} & \multirow[t]{2}{*}{.000} \\
\hline & CONTROL & 40 & 7.23 & 3.655 & & & \\
\hline \multirow[t]{2}{*}{ Cross words } & $\begin{array}{l}\text { EXPERIMENTA } \\
\mathrm{L}\end{array}$ & 48 & 11.29 & 2.432 & \multirow[t]{2}{*}{2.973} & \multirow[t]{2}{*}{86} & \multirow[t]{2}{*}{.004} \\
\hline & CONTROL & 40 & 8.70 & 5.426 & & & \\
\hline \multirow[t]{2}{*}{ Matching } & $\begin{array}{l}\text { EXPERIMENTA } \\
\mathrm{L}\end{array}$ & 48 & 12.50 & 3.281 & \multirow[t]{2}{*}{3.620} & \multirow[t]{2}{*}{86} & \multirow[t]{2}{*}{.000} \\
\hline & CONTROL & 40 & 9.70 & 3.976 & & & \\
\hline \multirow[t]{2}{*}{ Tot. achievement } & $\begin{array}{l}\text { EXPERIMENTA } \\
\mathrm{L}\end{array}$ & 48 & 34.35 & 6.781 & \multirow[t]{2}{*}{4.359} & \multirow[t]{2}{*}{86} & \multirow[t]{2}{*}{.003} \\
\hline & CONTROL & 40 & 25.63 & 11.729 & & & \\
\hline
\end{tabular}

A look at Table 3 below indicates that there was a significant difference between students who were put in a situation individually, pairs and groups. The mean scores of the students who were seated individually were 40.44 but the mean scores of the students who were in a situation pairs were 34.13 while that of the student who were in a seated of groups were 28.50. The results were in favor of the students who were seated individually. 
Table 3. Means and Standard Deviations of the Experimental Group on the Post Test (Individuals, Pairs and Groups)

\begin{tabular}{lllll}
\hline & & $\mathrm{N}$ & Mean & Std. Deviation \\
\hline Filling gaps & Ind & 16 & 12.81 & 2.536 \\
& Paired & 16 & 10.75 & 1.880 \\
& Group & 16 & 8.13 & 2.680 \\
Cross words & Total & 48 & 10.56 & 3.038 \\
& Ind & 16 & 12.88 & 2.527 \\
& Paired & 16 & 11.38 & 1.996 \\
& Group & 16 & 9.63 & 1.586 \\
Matching & Total & 48 & 11.29 & 2.432 \\
& Ind & 16 & 14.75 & .683 \\
& Paired & 16 & 12.00 & 3.688 \\
& Group & 16 & 10.75 & 3.276 \\
& Total & 48 & 12.50 & 3.281 \\
& Ind & 16 & 40.44 & 4.589 \\
& Paired & 16 & 34.13 & 4.731 \\
& Group & 16 & 28.50 & 4.953 \\
& Total & 48 & 34.35 & 6.781 \\
\hline
\end{tabular}

Table 3 presents mean scores for the experimental group (pairs, individuals and groups) on their performance for every activity type (matching, crossword and filling gaps).

A look at Table 3 shows that there was a difference between students' achievement in each activity type. The mean scores of students who were treated individually were 12.81 in the filling gaps, 12.88 in the crossword, and 14.75 in the matching activities. The mean scores of students who were treated in pairs was 10.75 in filling gaps, 11.38 in crosswords and 12.00 in matching activities, whereas the mean scores of students who were treated in groups was 8.13 in filling gaps, 9.63 in crosswords and 10.75 in matching. This means that there was a significant difference between the three activity types. Students' performance was better in matching activity, crosswords and filling gaps respectively. The mean scores of matching activities were 12.50 the mean scores of filling gaps was 10.56 whereas that of crosswords was 11.29 in favor of the matching activities.

Table 4. One way Analysis of variance of student's achievement due to technique

\begin{tabular}{lllllll}
\hline & & Sum of & & & & \\
& Squares & Df & Mean Square & F & Sig. \\
\hline Filling gaps & Between Groups & 176.625 & 2 & 88.313 & 15.452 & .000 \\
& Within Groups & 257.188 & 45 & 5.715 & & \\
& Total & 433.813 & 47 & & & \\
Cross words & Between Groups & 84.667 & 2 & 42.333 & 9.858 & .000 \\
& Within Groups & 193.250 & 45 & 4.294 & & \\
Matching & Total & 277.917 & 47 & & & \\
& Between Groups & 134.000 & 2 & 67.000 & 8.105 & .001 \\
& Within Groups & 372.000 & 45 & 8.267 & & \\
Tot. achievement & Total & 506.000 & 47 & & & \\
& Between Groups & 1141.292 & 2 & 570.646 & 25.183 & .000 \\
& Within Groups & 1019.688 & 45 & 22.660 & & \\
& Total & 2160.979 & 47 & & & \\
\hline
\end{tabular}


Table 4 below shows that there are significant differences according to the technique (individual, pair and group) of teaching. Students' performance was the best in individual technique. There are significant differences according to the activity types (matching, Crossword and filling gaps). Students' performance was the best in matching activity. However, there is no interaction between the technique of teaching and the activity type; see the table below.

To find whether these results were significant for which technique, the Post Hoc Analysis was used.

Table 5 shows that there were significant findings between the individual and the paired technique between the individual and the group technique, and between group and paired technique, in favor of the individual technique. This means that students' performance in individual technique was better than pair technique and students' performance in individual technique was better than the group technique. However, there were no significant differences in students' performance between group and pair technique.

To find whether findings about activity type were significant, Post Hoc Analysis was used. It was found that there were significant findings between filling gaps and matching, and also between crosswords and matching. However, there were no significant finding between filling gaps and crosswords. Students' performance was better in matching activity than filling gap and crossword. However, students' performance in filling gap and crossword was approximately the same; see Table 5.

Table 5. Post Hoc Analyses of the Pairs, Individuals and Groups Technique

LSD

\begin{tabular}{|c|c|c|c|c|c|}
\hline $\begin{array}{l}\text { Dependent } \\
\text { Variable }\end{array}$ & (I) METHOD & (J) METHOD & $\begin{array}{l}\text { Mean } \\
\text { Difference } \\
\text { (I-J) }\end{array}$ & Std. Error & Sig. \\
\hline \multirow[t]{6}{*}{ Filling gaps } & \multirow[t]{2}{*}{ Ind } & Paired & $2.06(*)$ & .845 & .019 \\
\hline & & Group & $4.69(*)$ & .845 & .000 \\
\hline & \multirow[t]{2}{*}{ Paired } & Ind & $-2.06(*)$ & .845 & .019 \\
\hline & & Group & $2.63(*)$ & .845 & .003 \\
\hline & \multirow[t]{2}{*}{ Group } & Ind & $-4.69(*)$ & .845 & .000 \\
\hline & & Paired & $-2.63(*)$ & .845 & .003 \\
\hline \multirow[t]{6}{*}{ Cross words } & \multirow[t]{2}{*}{ Ind } & Paired & $1.50(*)$ & .733 & .046 \\
\hline & & Group & $3.25(*)$ & .733 & .000 \\
\hline & \multirow[t]{2}{*}{ Paired } & Ind & $-1.50\left(^{*}\right)$ & .733 & .046 \\
\hline & & Group & $1.75(*)$ & .733 & .021 \\
\hline & \multirow[t]{2}{*}{ Group } & Ind & $-3.25(*)$ & .733 & .000 \\
\hline & & Paired & $-1.75(*)$ & .733 & .021 \\
\hline \multirow[t]{6}{*}{ Matching } & \multirow[t]{2}{*}{ Ind } & Paired & $2.75(*)$ & 1.017 & .010 \\
\hline & & Group & $4.00(*)$ & 1.017 & .000 \\
\hline & \multirow[t]{2}{*}{ Paired } & Ind & $-2.75(*)$ & 1.017 & .010 \\
\hline & & Group & 1.25 & 1.017 & .225 \\
\hline & \multirow[t]{2}{*}{ Group } & Ind & $-4.00(*)$ & 1.017 & .000 \\
\hline & & Paired & -1.25 & 1.017 & .225 \\
\hline \multirow{6}{*}{$\begin{array}{l}\text { Tot. } \\
\text { achievement }\end{array}$} & \multirow[t]{2}{*}{ Ind } & Paired & $6.31(*)$ & 1.683 & .001 \\
\hline & & Group & $11.94(*)$ & 1.683 & .000 \\
\hline & \multirow[t]{2}{*}{ Paired } & Ind & $-6.31(*)$ & 1.683 & .001 \\
\hline & & Group & $5.63(*)$ & 1.683 & .002 \\
\hline & \multirow[t]{2}{*}{ Group } & Ind & $-11.94(*)$ & 1.683 & .000 \\
\hline & & Paired & $-5.63(*)$ & 1.683 & .002 \\
\hline
\end{tabular}

* The mean difference is significant at the .050 level. 


\section{Discussion of the Results of the Firstquestion}

The first question tests if there are any significant statistical differences on students achievement in English attributed to learning by computer games and learning traditionally. The results revealed that computer games were useful means for students learning of English.

The pre test showed that there was no statistically significant difference between the achievement of the experimental and control groups, indicating that the two groups were equivalent before conducting the study. The means were 18.85 for the experimental group and 16.48 for the control group.

Comparing the achievement of the experimental group and that of the control group in the post test, results indicated that there was a statically significant difference between the two groups. The means were 34.35 for the experimental group and 25.63 for the control group in favor of experimental group. These differences in the students' achievement in English were attributed to the method of instruction used in the study and in favor of the experimental group.

In the researcher's point of view, using computer games gives students more opportunities to practice the four skills (listening, speaking, reading and writing). At the same time students felt very happy while working on computers; they were smiling, laughing and clapping. They were highly motivated.

Moreover, every student took his/her chance in practicing the games. The slow learners took their time to play and answer, while the fast students worked fast. At the same time, students felt more confident; they did not hesitate while answering the questions.

Giving students the chance to be involved in the games is a very important issue. It facilitates learning and gives students the desire and motivation to learn more and at the same time, it helps students' retention. There is a Chinese proverb saying that "tell me and I will forget, teach me and I will remember, involve me and I will learn" Vilmi (2001).

These results are consistent with the results reported by Al Faqih (1995) who found that there are a statistically differences utilizing computer games. Al Madi (2002) also supports these findings as she says that using computer assisted English language instruction has effect on the experimental group pupils' vocabulary achievement. Jaradat (2009) also agrees with these findings and he said that there are significant differences in mean scores between the experimental and instructional method used.

\section{Discussion of the Results of the Second Question}

This question investigates if there are any significant statistical differences in the students' achievement attributed to the technique of teaching (individual, pairs and groups). One-way ANCOVA showed that there were statistically significant differences between the three groups (pairs-individual and groups). Comparing the achievement of the three groups, the results showed that the mean scores of the individual group was 40.44 and that of pairs was 34.13 and the mean scores of the group was 28.50 , which indicates that the results were in favor of the individuals technique.

Since the result of individual learning technique was higher than pairs or groups and it was found more effective, the researcher thinks that students in the individual learning technique took the chance to concentrate on material and practice it in a good environment; this means that depending on students individual learning technique can improve students learning of English. Probably, this may be attributed to the fact that some students like the atmosphere of games, and each wants to enjoy more. This is against the results reported by Yiping Lou (2001) that small group learning with technology had significantly more positive effects than individual learning on students' achievement. Moreover, this is against the results reported by David (1998) about the effects of individual and cooperative computer-assisted instruction on students' performance and attitudes. The results of their study indicated that students who worked cooperatively significantly outperformed those who worked individually.

\section{Discussion of the Results of the Third Question}

This question investigates if there are any statistical differences in the students' achievement on English attributed to the interaction between the activity type and the technique of teaching (groups, pairs and individuals).

Post Hoc analysis showed that there was no significant statistical difference related to the interaction between the activity type, and the technique of teaching. Moreover, the results showed that there were significant differences in the student's achievement attributed to the activity types. It was found that students' performance was better in 
matching than crossword and filling gap. The mean scores of students' achievement on the matching activities were $12.50,10.56$ in filling gaps and 11.29 in crosswords.

Comparing students' achievement in technique (pairs, individuals and groups) and the three activity types, the results showed that student got higher achievement in matching activity, then in crosswords and the lower achievement was in the filling gaps activities. This means that students found matching activity easier than filling gap and crossword.

The researcher believes that learning by games is a functional aid with which a learner can acquire a foreign language easily, so it is important to plan for making the computer games. It is important to choose a suitable activity for students in order to improve students' learning of English.

The findings of this study could also be attributed to the time (6weeks) which the students were trained through computer games. Besides, students were very happy because they were engaged in learning.

\section{Recommendations}

In the light of the findings of this study, the following recommendations are directed to the Ministry of Education, teachers, instructors and researchers:

1) Teachers of English should use computer games in the teaching process.

2) The Ministry of Education can activate the role of computer games and adapt them in its curricula.

3) Similar studies for other classes and bigger samples can be conducted in order to make the results widely applicable.

4) Schools should be provided with computers so that students could have the chance to learn individually.

\section{References}

$\mathrm{Al}$ - Abbadi, Hamed. (2005). Effects of using computer games as an instructional tool on third grade students', Acquisition of higher order thinking skills. Jordan Journal of Educational Sciences, 2, 143-148.

Al Madi, Bayan. (2002). The effects of using computer instructional on achievement in English of 11th scientific grade. Unpublished MA thesis, Al al-Bayt University. Mafraq Jordan.

Alfaqih, A. (1995). The effect of using games in English language teaching on the seventh graders achievement in Jordan. Unpublished MA thesis, Yrmouk University, Irbid, Jordan.

Amory, A., \& Adams C. (1999). The use of computer games as an educational tool. British Journal of Educational Technology, 30(4), 310-319. http://dx.doi.org/10.1111/1467-8535.00121

Betz, J. (1995). Computer games: increases learning in an interactive multidisciplinary environment. Journal of Educational Technology System, 24(4), 195-205. http://dx.doi.org/10.2190/119M-BRMU-J8HC-XM6F

Cratty, B. (1969). Development games for physically handicapped children. PALO Alto. California: T.H Peek publishing.

David, W. (1998). Effects of individual and cooperative computer-assisted instruction on student performance and attitudes. Educational Technology Research and Development, 37(2).

Gardner, D. (1998). Communication Games Do we know what are we talking a bout? ELT Journal, 41(1), 19- 24. $\mathrm{http}: / / \mathrm{dx}$. doi.org/10.1093/elt/41.1.19

Gass, S. (1997). Input, interaction and the development of second language. Mahwah, NJ: Eribaum.

Hansson, T. (2005). English as a second language on a virtual platform: Traditional and innovation in anew $\begin{array}{lllll}\text { medium. } & \text { Computer Assisted Language Learning, 18(182), }\end{array}$ http://dx.doi.org/10.1080/09588220500132332

Jaradat, A. (2009). The effect of a computerized program on tenth grade students' learning of English vocabulary. M.A Thesis. Yarmuk University. Irbid :Jordan.

Keen, J. (1995). A study of the effects of a games approach for spelling instruction. Unpublished Doctoral Dissertation. Virginia Polytechnic Institute and State University, USA.

Kim, L. (1995). Creative games for the language class. English Teaching Forum, 33(1), 35- 42.

Lee, W. (1987). Language teaching games and contents. Oxford: Oxford University.

Lewis, J. (1999). Using games in an EFL class for children. English Teaching Forum, 29(3), 30-31. 
Peterson, M. (2010). Computerized games and simulations: Ameta Analysis of research. Computer-Assisted Language Learning, 41(1), 72-93. Retrieved May 8, 2010, from http://search ebschost.com

Richard-Amato, P. (1988). Making it happen: Interaction in the second language classroom: From theory to practice. New York: Longman.

Rieber, L. (1996). Seriously considering play: designing interactive learning micro worlds, simulation, and games. Educational Research in Education, 18, 191 - 251.

Sorensen, Elsebeth. (2009). Interactive Whiteboards and Computer Games at High School Level: Digital Resources for Enhancing Teaching and Learning. Proceeding of the European Conferece on Games Based Learning, 345-353. Retrieved May 22, 2010, from www.ebscohost.com

Stephenson, P., \& Rumley, G. (2005). Inclusive work at a European level. A case study. Support of Learning, 20(3), 141-45. http://dx.doi.org/10.1111/j.0268-2141.2005.00378.x

Vilmi, R. (2001). Learning to play, playing to learn: Using games as educational tools. Modern English Teacher, 10(2), 32-39.

Williams, M. (1985). 40 Thinking games to make and play. Cheltenham, U.K. Nelson Thornes (Publishers) Ltd.

Yiping, L. (2010). Small group and individual learning technology: Ameta -Analysis. Revew of Educational Resrach, 71(3), 449-521. Retrieved May 8, 2010, from http: rer.sagepub.com

\section{Index}

Index (1).

بسم اله الرحمن الرحيم

Directorate of Education of theAL-SALT Governorate

/ Pre-Post test

Name :

Subject : English

Time : An hour \& a half

Class : $3^{\text {rd }}$ Grade

Date :

Answer the following question :

(1). A. Fill the gaps with the correct word: (5 points)

1. $\mathrm{He}$ playing Football ( am, is, are )

2. she watching television (is, are, am )

3. Lions are than rabbits. (big, bigger, biger )

4. Is she buying juice? (No, she isn't / No, he isn't / No, she is )

5. We drink cola. (must, mustn't, musn't )

B. Fill the gaps with the correct word:

(5 points)

a. Laila likes eating (apple, clothes, football)

b. I play every day (banana, water, football)

c. she is wearing a beautiful (meat, book, dress )

d. January is a (day, year, month)

e. Lions are (animals, people, months)

C. Fill the gaps with the following list of words: (5 points)

( 1. football, 2. clean, 3.wears, 4. camels, 5. rubbish )

1. They their teeth every day.

2._ are heavy animals.

3. I am watching a match now.

4. You have to put in the bin. 
5. My sister a beautiful dress.

(2). A. Find the months and complete: (5 points )

\begin{tabular}{|l|l|l|l|l|l|l|l|l|l|l|}
\hline J & a & N & u & a & r & y & o & M & A & Y \\
\hline S & e & P & t & e & m & b & e & R & N & O \\
\hline N & m & A & r & c & h & s & j & U & N & E \\
\hline Z & f & G & i & t & j & d & n & M & E & R \\
\hline W & m & N & w & r & d & h & t & O & u & T \\
\hline
\end{tabular}

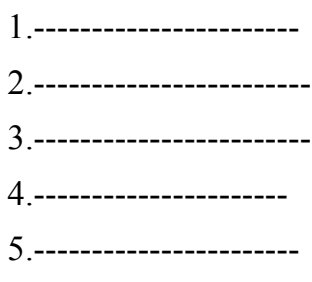

B. Find the adjectives and complete: ( 5 points )

\begin{tabular}{|l|l|l|l|l|l|l|}
\hline T & a & l & L & i & t & h \\
\hline B & l & i & O & n & p & e \\
\hline I & s & n & A & i & l & a \\
\hline G & f & a & S & t & a & v \\
\hline E & o & s & T & o & h & y \\
\hline S & m & a & L & l & y & r \\
\hline
\end{tabular}

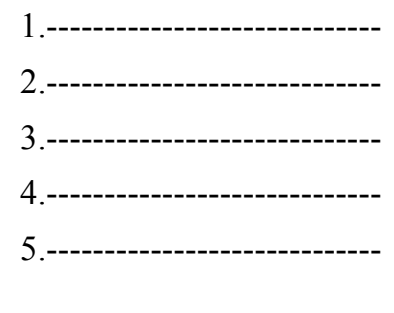

\section{Find the colors: ( 5 points )}

\begin{tabular}{|l|l|l|l|l|l|l|}
\hline R & b & L & A & c & k & g \\
\hline E & p & h & L & r & t & r \\
\hline D & i & k & L & r & t & e \\
\hline I & n & F & L & o & p & e \\
\hline R & k & d & R & e & s & n \\
\hline Y & a & L & L & o & w & n \\
\hline
\end{tabular}

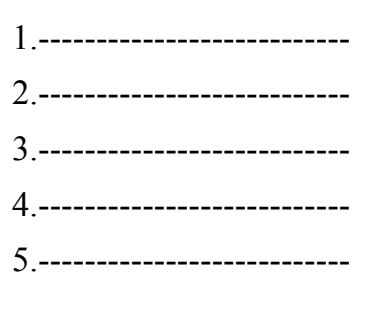

3. A. Match the verbs with the nouns: (5 points)
1. Play
a. orange juice
2. Drink
b. the park
3. Go to
c.football
4. Wear
d. a dress

5. Watch

e.televesion

B. Match the words with the pictures: (5 points)
1. Rug
2. Blouse
3. Skirt
4. Dress
5. Boots
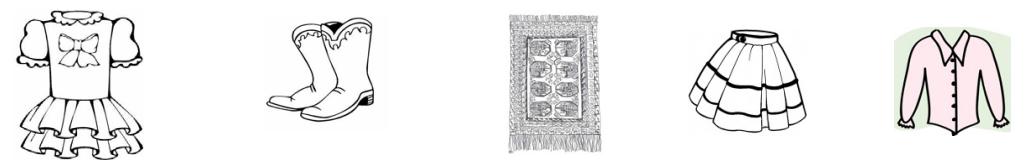

C. Match the animals with the pictures: (5 points)
1. Lion
2. Elephant
3. Camel
4. Tiger
5. Giraffe
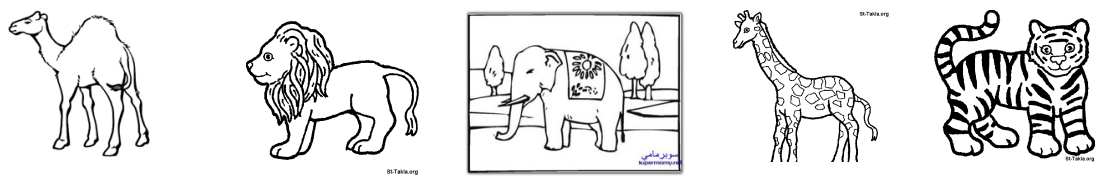

The End

Good Luck 
Index (2).

Answer key of the test

Question one
A)
B)
C)
1) is
1) apple
1) clean
2) is
2) football
2) camels
3) bigger
3) dress
3) football
4) no, she isn't
4) month
4) rubbish
5) mustn't
5) animals
5) wears

Question two
A)
B)
C)
1) January
1) tall
1) black
2) September
2) big
2) red
3) March
3) small
3) green
4) June
4) fast
4) yellow
5) May
5) heavy
5) Pink

Question three
A) 1) football
2) orange juice
3) the park
4) a dress
5) television 